\title{
Phosphorus-31 nuclear magnetic resonance assignments of biogenic phosphorus compounds in sediment of an artificial Fuyangxin River, China
}

\author{
Wenqiang Zhang • Baoqing Shan • Hong Zhang • \\ Wenzhong Tang
}

Received: 6 April 2013 / Accepted: 4 November 2013 / Published online: 28 November 2013

(C) Springer-Verlag Berlin Heidelberg 2013

\begin{abstract}
River eutrophication could drastically influence the phosphorus $(\mathrm{P})$ in the water and sediment. To understand the biogenic-P species, distribution and bioconversion, five sediment samples were collected from an artificial river, and analyzed by phosphorus-31 nuclear magnetic resonance $\left({ }^{31} \mathrm{P}-\mathrm{NMR}\right)$. The $\mathrm{P}$ pollution in the water and sediment were both severe. The average concentrations of total P (TP) and solution reactive phosphorus in the water were 3.0 and $2.6 \mathrm{mg} \mathrm{L}^{-1}$, respectively, which surpass grade V of the national quality standard (China) and should not be used for any purpose. The river sediments accumulated significant inorganic phosphorus $(\mathrm{Pi})$ and organic phosphorus $(\mathrm{Po})$; in the $\mathrm{P}$ fractionation, the rank order of the $\mathrm{P}$ fractions was as follows: $\mathrm{Ca}-\mathrm{P}>\mathrm{NaOH}-\mathrm{Pi}>\mathrm{Res}-\mathrm{P}>\mathrm{KCl}-\mathrm{P}>\mathrm{NaOH}-\mathrm{Po}$, with average relative proportions of 25.1:16.8:6.6:1.7:1:0. Six P compounds were detected in the $\mathrm{NaOH}-\mathrm{EDTA}$ extract by ${ }^{31} \mathrm{P}$ NMR. Mono-P (8.96-29.58 \%) was the dominant forms of biogenic-P, and other smaller fractions of biogenic-P were also observed, including pyro-P (0.22-0.86\%), DNA-P (0.75$2.03 \%$ ), phon-P (0-1.57\%), and lipids-P (0-2.66\%). The $\mathrm{TP}$ and biogenic-P decreased along the direction of flows, with their average relative proportions 7.97:1.20:1.49:1.00:1.00 and 40.87:2.34:3.46:1.60:1 from the upstream to downstream, respectively. The concentration and species of $\mathrm{Po}$ in $\mathrm{NaOH}-\mathrm{Po}$
\end{abstract}

Responsible editor: Hailong Wang

Electronic supplementary material The online version of this article (doi:10.1007/s11356-013-2322-5) contains supplementary material, which is available to authorized users.

W. Zhang $\cdot$ B. Shan $(\bowtie) \cdot H$. Zhang $\cdot$ W. Tang

State Key Laboratory on Environmental Aquatic Chemistry,

Research Center for Eco-Environmental Science, Chinese Academy

of Science, Beijing 100085, China

e-mail: bqshan@rcees.ac.cn

W. Zhang

University of Chinese Academy of Science, Beijing 100049, China were lower than found in ${ }^{31} \mathrm{P}-\mathrm{NMR}$ analysis in this research. Thus, the use of $0.25 \mathrm{M} \mathrm{NaOH}$ and $50 \mathrm{mM}$ EDTA extracts and solution ${ }^{31} \mathrm{P}-\mathrm{NMR}$ analysis was a more accurate method for quantifying biogenic-P in the river sediments than $\mathrm{P}$ fractionation.

Keywords Phosphorus · Artificial river · Sediment · ${ }^{31} \mathrm{P}-\mathrm{NMR}$

\section{Introduction}

Phosphorus $(\mathrm{P})$ is a primary element in freshwater ecosystems (Cade-Menun et al. 2006). P from agriculture, industrial, and municipal sources can lead to or worsen the eutrophication of freshwater, which results in water quality deterioration (Carpenter 2008). Many artificial rivers were constructed to reduce the flood hazard in the Haihe River Basin of northern China in the 1950s and 1960s of the twentieth century. Within the past 30 years, the Haihe River Basin has faced the highest rate of increase in population and economic development in China. Large amounts of wastewater from agriculture, domestic, and industrial sources are discharged into the artificial rivers, the function of which has been changed from flood control to receptacles for sewage. As a result, the nutrient $(\mathrm{P})$ concentration has massively increased in the past 30 years (Pernet-Coudrier et al. 2012). The artificial rivers have smaller river curvature, a simple littoral zone and lack of change in river morphology. These rivers are located in the plain areas, which have been regions of intensified farming and dense population. Their extensive $\mathrm{P}$ input and peculiar river morphology make the $\mathrm{P}$ biogeochemical cycle in artificial rivers worthy of attention.

River sediment plays a vital role as a reservoir of external $\mathrm{P}$ and source of internal P (Rusu et al. 2012). The biogeochemical cycles of $\mathrm{P}$ in artificial river sediment are complicated, 
including physical, chemical, and biological processes (Golterman 2001; Schauser et al. 2006; Liu et al. 2009). Sediment $\mathrm{P}$ includes inorganic phosphorus (Pi) and organic phosphorus (Po). Several analytical methods have been developed to elucidate Po compounds, including $\mathrm{P}$ fractionation and study of the Po fraction using various extracts to distinguish different $\mathrm{P}$-forms binding to metals $(\mathrm{Fe}, \mathrm{Al})$ or organic matter (Hieltjes and Lijklema 1980; Pierzynski 2004). Although these methods have provided useful information pertaining to $\mathrm{P}$ biogeochemical cycling in aquatic environments, they have not yielded sufficient insight into identification of specific P compounds (Brandes et al. 2007). Nuclear magnetic resonance (NMR) is a powerful analysis tool for environmental science, and phosphorus-31 nuclear magnetic resonance $\left({ }^{31} \mathrm{P}-\mathrm{NMR}\right)$ spectroscopy distinguishes different $\mathrm{P}$ groups based on specific resonance frequencies, reflecting the chemical environment surrounding the $P$ nuclei (Cardoza et al. 2004; Reitzel et al. 2006a, b). ${ }^{31} \mathrm{P}-\mathrm{NMR}$ is a non-destructive, non-invasive technique for identifying chemical forms that has the advantage of enabling multiple $\mathrm{P}$ compounds to be characterized simultaneously with distinct binding properties (Cade-Menun 2005). Therefore, it is an ideal technique for use in analysis of Po species in marine or freshwater sediment. Many $\mathrm{P}$ species are detected by ${ }^{31} \mathrm{P}-\mathrm{NMR}$, including phosphonates, orthophosphate, orthophosphate monoesters, orthophosphate diesters (lipids-P and DNA-P), pyrophosphate, and polyphosphate (Cade-Menun et al. 2005). Therefore, it is an ideal technique for use in analysis of Po species in freshwater sediments, which not only provides sufficient insight into identification of specific $\mathrm{P}$ compounds, but also offers useful information pertaining to $\mathrm{P}$ biogeochemical cycling in the aquatic environment. ${ }^{31} \mathrm{P}-\mathrm{NMR}$ has been used to analyze single Po or Po compounds (Bai et al. 2009; Orchard et al. 2010), the P transformation and effect factors (Ahlgren et al. 2005; Reitzel et al. 2007), P biogeochemistry (Shinohara et al. 2012), and aluminum dosing effects on eutrophication management (Reitzel et al. 2006a, b, 2009).

Fuyangxin River was in the Hebei province, which mainly accepts sewage from Shijiazhuang, Handan, and other cities. As the economic development and land used change, more and more sewage water flow to this river. For example, the area of city increased 179.05 and $72.00 \mathrm{~km}^{2}$ from 1980 to 2005 in Shijiazhuang and Handan, respectively, and the sewage water were also increased 85,290 and 37,020 kt from 1980 to 2005 in Shijiazhuang and Handan, respectively. Although some environmental regulations and future environmental policy perspective was drafted, such as the twelfth five-year guideline of the ecological protection in Hebei, Hebei water pollution control ordinance, and Shijiazhuang city drinking water source protection areas groundwater pollution prevention and control regulations, abundant of $\mathrm{P}$ flow to the river as sewage. Because of the different morphological characteristics, the $\mathrm{P}$ species and cycle might be different to natural rivers. In this study, surface sediment and water quality were researched in Fuyangxin River. P was analyzed by P fractionation and solution ${ }^{31} \mathrm{P}-\mathrm{NMR}$. The extract of $\mathrm{NaOH}-$ total phosphorous (TP) in P fractionation was also analyzed by ${ }^{31} \mathrm{P}-\mathrm{NMR}$. Through this research, we will identify the $\mathrm{P}$ compounds in the surface sediment of the Fuyangxin River and the relationship between $\mathrm{P}$ compounds and water quality and other factors of the river, and the variation of $\mathrm{P}$ compounds in artificial river systems. This study may provide deep insight into $\mathrm{P}$ biogeochemical cycling in artificial river systems.

\section{Materials and methods}

\section{Site description}

The Haihe River Basin, with area of about $300,000 \mathrm{~km}^{2}$ and population of 145 million, is located in northern China. Beijing, Tianjin, and many other cities are included in this river basin, and its urbanization level is over $45 \%$. The Fuyangxin River (N $37^{\circ} 30^{\prime}-38^{\circ} 11^{\prime}$, E $115^{\circ} 03^{\prime}-116^{\circ} 04^{\prime}$ ) is an important component of the Haihe river system. The length of the main channel is $133 \mathrm{~km}$ and width is 1,600 to $1,700 \mathrm{~m}$, crossing the cities of Hengshui and Xingtai. The Fuyangxin River was built during 1967 to 1968 for improve the Fuyang River flood discharge capacity. This river mainly accepts the floods from the Beili River, Xiao River, and Fuyang River. With its high growth in economic development and population, the region faces increasing water scarcity and water pollution. The Fuyangxin River has become a river that mainly accepts sewage from Shijiazhuang, the capital of Hebei province, Xingtai, Handan, and other cities. The high pollution discharge results in the deterioration of water quality, and $\mathrm{P}$ is the primary pollutant in the Fuyangxin River. A total of five sampling sites were set up over the whole river. Site 1 was set up near Aixinzhuang Dam. Site 2 was located upstream of Hengshui city, and sites 3, 4, and 5 were set up downstream of Hengshui city successively (Fig. 1).

\section{Sample collection and analysis}

Sediment sample collection was conducted in July 2012. Three surface (about $5 \mathrm{~cm}$ ) sediment samples of each site were collected by Peterson grab sampler (the distance between the three parallel samples was not less than $500 \mathrm{~m}$ ). Samples at the same site were pooled and homogenized to obtain a representative sample. All samples were frozen and stored at $-18{ }^{\circ} \mathrm{C}$ immediately. Water samples were collected at the surface and water quality was monitored from 2010 to 2012 .

Total $\mathrm{P}$ in sediment was measured by treating at $500{ }^{\circ} \mathrm{C}$ $(2 \mathrm{~h})$, followed by $1 \mathrm{~mol} \mathrm{~L}^{-1} \mathrm{HCl}$ extraction $(16 \mathrm{~h})$. Pi was determined by direct extraction with $1 \mathrm{~mol} \mathrm{~L}^{-1} \mathrm{HCl}(16 \mathrm{~h})$. Po concentrations in the sediments were calculated as the 


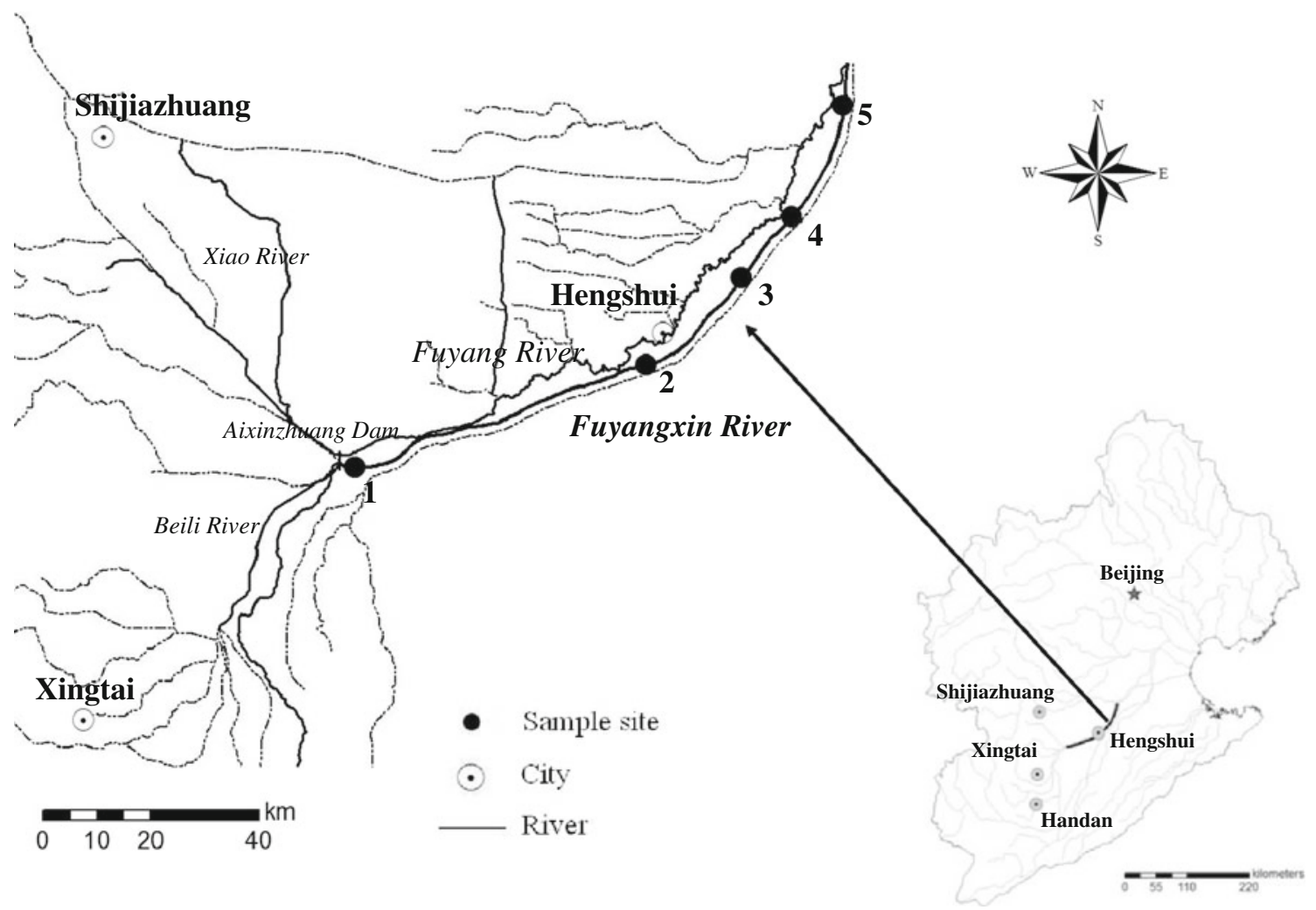

Fig. 1 Location of sampling sites in Fuyangxin River

difference between TP and Pi (Aspila et al. 1976). Total Fe, $\mathrm{Al}, \mathrm{Mg}, \mathrm{Mn}$, and $\mathrm{Ca}$ were measured using ICP-OES/MS after digesting sediments with $\mathrm{HNO}_{3}$ - $\mathrm{HCl}$-HF (MARSXpress, CEM, USA). Sample $\mathrm{pH}$ was determined in a sediment suspension in deionized water with a sediment/water ratio of $1: 2.5$. Organic matter $(\mathrm{OM})$ in sediments was analyzed as the loss on ignition at $550{ }^{\circ} \mathrm{C}$ for $4 \mathrm{~h}$ (Jensen et al. 1992). TP in the water was measured using the molybdenum blue method. An annual average for TP in the water column was calculated for each site by using the monitoring data from 2010 to 2012. Three replicates were performed for each index, and the mean value was calculated (Wang and Pant 2012).

The $\mathrm{P}$ fractionation procedure was primarily based on the Hieltjes-Lijklema scheme (Hieltjes and Lijklema 1980). P in the sediment was classified into KCl-P, NaOH-Pi, NaOH-Po, $\mathrm{Ca}-\mathrm{P}$, and Res-P. KCl-P was extracted with $1 \mathrm{M} \mathrm{KCl}$ for $1 \mathrm{~h}$ with shaking at room temperature (about $25^{\circ} \mathrm{C}$ ). Then the sediment was extracted with $0.1 \mathrm{M} \mathrm{NaOH}$ for $17 \mathrm{~h}$ with shaking at room temperature. $\mathrm{NaOH}-\mathrm{Pi}$ and $\mathrm{NaOH}-\mathrm{TP}$ were analyzed using the molybdenum blue method before and after digestion by potassium persulfate $\left(\mathrm{K}_{2} \mathrm{~S}_{2} \mathrm{O}_{8}\right)$. NaOH-Po was calculated as their difference. Ca-P was extracted with $0.25 \mathrm{M}$ $\mathrm{H}_{2} \mathrm{SO}_{4}$ for $1 \mathrm{~h}$ with shaking at $25^{\circ} \mathrm{C}$. The Res-P was the difference of TP in sediment and KCl-P, NaOH-TP, and Ca-P. The $\mathrm{P}$ concentration in all extracts was estimated colorimetrically according to the method by Murphy and Riley (1962). In order to detect the $\mathrm{P}$ compounds in the $\mathrm{NaOH}-\mathrm{TP}$, the $\mathrm{NaOH}$ -
TP extract was freeze-dried and then dissolved with $0.6 \mathrm{ml}$ $\mathrm{D}_{2} \mathrm{O}$ and $0.1 \mathrm{ml} 10 \mathrm{~mol} \mathrm{~L}^{-1} \mathrm{NaOH}$, ultrasonicated for $30 \mathrm{~min}$ and then equilibrated for $5 \mathrm{~min}$. Two percent $(v / v)$ of bicarbonate-buffered dithionite $\left(0.11 \mathrm{M} \mathrm{NaHCO}_{3}+0.11 \mathrm{M}\right.$ $\mathrm{Na}_{2} \mathrm{~S}_{2} \mathrm{O}_{4}$ ) was added to extracts to reduce interference from paramagnetic ions, such as $\mathrm{Fe}$ and $\mathrm{Mn}$. The supernatants were centrifuged for $15 \mathrm{~min}$ at 14,000 rpm and transferred to 5-mm NMR tubes for ${ }^{31} \mathrm{P}-\mathrm{NMR}$ analysis.

\section{${ }^{31} \mathrm{P}-\mathrm{NMR}$ analysis}

Three grams of sediment samples were pre-extracted with $30 \mathrm{ml}$ of a solution composed of $0.05 \mathrm{~mol} \mathrm{~L}^{-1}$ EDTA+ $0.25 \mathrm{~mol} \mathrm{~L}^{-1} \mathrm{NaOH}$ for $16 \mathrm{~h}$ at room temperature (Turner et al. 2003a). An aliquot of the NaOH-EDTA extracts was used to analyze $\mathrm{Pi}$ (Pi in NaOH-EDTA) and TP (TP in NaOHEDTA) using the molybdenum blue method before and after digestion by potassium persulfate $\left(\mathrm{K}_{2} \mathrm{~S}_{2} \mathrm{O}_{8}\right)$. The Po in extractions was calculated as their difference. The remaining solution was frozen and lyophilized and used for ${ }^{31} \mathrm{P}-\mathrm{NMR}$ analysis. Some studies have shown that freezing the extracts does not alter the P composition (Hupfer et al. 1995, 2004).

Of the lyophilized extracts, $0.3 \mathrm{mg}$ was re-dissolved in $0.6 \mathrm{ml} \mathrm{D}_{2} \mathrm{O}$ and $0.1 \mathrm{ml} 10 \mathrm{~mol} \mathrm{~L}^{-1} \mathrm{NaOH}$, ultrasonicated for $30 \mathrm{~min}$ and then equilibrated for $5 \mathrm{~min}$. Two percent $(v / v)$ of bicarbonate-buffered dithionite $\left(0.11 \mathrm{M} \mathrm{NaHCO}_{3}+0.11 \mathrm{M}\right.$ $\mathrm{Na}_{2} \mathrm{~S}_{2} \mathrm{O}_{4}$ ) was added to extracts to reduce interference of 
paramagnetic ions, such as $\mathrm{Fe}$ and $\mathrm{Mn}$. The supernatants were centrifuged for $15 \mathrm{~min}$ at 14,000 rpm and transferred to $5-\mathrm{mm}$ NMR tubes. Solution ${ }^{31} \mathrm{P}-\mathrm{NMR}$ spectra were obtained using a Bruker $400 \mathrm{MHz}$ spectrometer (Bruker, Billerica, MA, USA) operating at $129.53 \mathrm{MHz}$ at $25^{\circ} \mathrm{C}$. We used a $90{ }^{\circ} \mathrm{C}$ observation pulse, relaxation delay $2 \mathrm{~s}$, and acquisition time $0.6 \mathrm{~s}$. Spectra were collected with around 20,000 scans and the spectra were taken at around $14 \mathrm{~h}$ (Beijing NMR center, Beijing). Chemical shifts were recorded relative to an $85 \%$ $\mathrm{H}_{3} \mathrm{PO}_{4}$ standard $(\delta=0 \mathrm{ppm})$. Signals were assigned to $\mathrm{P}$ species based on data in the literature reports (Turner et al. 2003b; Cade-Menun 2005). The peak area was calculated by visual inspection and an automated peak analysis tool. From the different $\mathrm{P}$ species areas, the contribution of each of the $\mathrm{P}$ compound groups (ortho-P, phon-P, pyro-P, mono-P, and diesters-P (DNA-P and lipid-P)) was calculated relative to the TP in the NaOH-EDTA extraction determined by the molybdenum blue method. The author verified the chemical shifts of $\mathrm{P}$ compounds by carrying out spike experiments using known compounds to assign peaks (such as $\mathrm{Na}_{4} \mathrm{P}_{2} \mathrm{O}_{7} \cdot 10 \mathrm{H}_{2} \mathrm{O}$ ) (Wang and Pant 2010c).

\section{Results}

Sediment and water characteristics

$\mathrm{TP}$ in the water and sediment characteristics are shown in Table 1. For the five sediments, the concentration of TP varied greatly, ranging from 852.38 to $6,804.10 \mathrm{mg} \mathrm{kg}^{-1}$. The highest concentration appeared at point 1 , which was near Aixinzhuang Dam, and was nearly $7,000 \mathrm{mg} \mathrm{kg}^{-1}$. The average of TP was $2,160.29 \mathrm{mg} \mathrm{kg}^{-1}$ and the Pi was the main P fraction. The concentration of Po, which accounted for 15.6 to $42.8 \%$, ranged from 132.93 to $2,909.98 \mathrm{mg} \mathrm{kg}^{-1}$. The concentration of total $\mathrm{Al}$ was from 18.42 to $31.71 \mathrm{~g} \mathrm{~kg}^{-1}$, which was the same as that in an artificial lake $\left(21.82 \mathrm{~g} \mathrm{~kg}^{-1}\right.$, Liu et al. 2009), lower than Taihu Lake (61.72 $\mathrm{g} \mathrm{kg}^{-1}$, Bai et al. 2009) and higher than the Bronx River $\left(0.34 \mathrm{~g} \mathrm{~kg}^{-1}\right.$, $0.34 \mathrm{~g} \mathrm{~kg}^{-1}$ (oxalate-extractable), Wang and Pant 2010b). The concentration of total $\mathrm{Ca}$ ranged from 12.17 to $17.19 \mathrm{~g} \mathrm{~kg}^{-1}$, which was higher than the Bronx River (7.72 $\mathrm{g} \mathrm{kg}^{-1}$ (HCl-extractable), Wang and Pant 2010b) and Taihu Lake (7.91 $\mathrm{g} \mathrm{kg}^{-1}$, Bai et al. 2009) and lower than an artificial lake (44.72 $\mathrm{g} \mathrm{kg}^{-1}$, Liu et al. 2009). The concentration of total Fe ranged from 34.38 to $43.63 \mathrm{~g} \mathrm{~kg}^{-1}$, which was higher than that in an artificial lake $\left(27.16 \mathrm{~g} \mathrm{~kg}^{-1}\right.$, Liu et al. 2009), Taihu Lake (32.42 $\mathrm{g} \mathrm{kg}^{-1}$, Bai et al. 2009), and the Bronx River (5.20 $\mathrm{g} \mathrm{kg}^{-1}$ (oxalate-extractable), Wang and Pant 2010b). The concentration of total $\mathrm{Mg}$ ranged from 3.47 to $4.10 \mathrm{~g} \mathrm{~kg}^{-1}$, which was higher than that in the Bronx River (2.29 $\mathrm{g} \mathrm{kg}^{-1}$ (HCl-extractable), Wang and Pant 2010b). The concentration of total $\mathrm{Mn}$ ranged from 0.43 to
$0.66 \mathrm{~g} \mathrm{~kg}^{-1}$, which was the same as that in an artificial lake $\left(0.58 \mathrm{~g} \mathrm{~kg}^{-1}\right.$, Liu et al. 2009). The $\mathrm{pH}$ ranged from 6.69 to 8.53 , and the average of $\mathrm{pH}$ was 7.59 . The concentrations of OM varied along with those of TP in the sediments, which ranged from 4.15 to $18.45 \%$, and the average of OM was $7.62 \%$. TP and solution reactive phosphorus (SRP) in water also varied greatly, ranging from 2.23 to $3.48 \mathrm{mg} \mathrm{kg}^{-1}$ and 1.52 to $3.58 \mathrm{~m} \mathrm{~kg} \mathrm{k}^{-1}$, respectively. The EC of sediments were $2,224.0,422.2,1,636.0,459.9$, and $1,518.0 \mu \mathrm{sm}^{-1}$, and the $\mathrm{EC}$ of the water were 5,786.6, 1,879.5, 3,177.0, 1,789.0, and $2,855.7 \mu \mathrm{s} \mathrm{cm}^{-1}$ as the river flow from site 1 to site 5 .

Phosphorus fractionation in sediments

The results from $\mathrm{P}$ fractionation in the sediment are shown in Fig. 2. The rank order of the $\mathrm{P}$ fractions was as follows: $\mathrm{Ca}-\mathrm{P}>$ $\mathrm{NaOH}-\mathrm{Pi}>\mathrm{Res}-\mathrm{P}>\mathrm{KCl}-\mathrm{P}>\mathrm{NaOH}-\mathrm{Po}$, with their average relative proportion 25.1:16.8:6.6:1.7:1:0 (the proportion was based on the average proportion of the NaOH-Po). Ca-P and $\mathrm{NaOH}-\mathrm{Pi}$ were the dominant fractions of sediment $\mathrm{P}$ in the sediment, and ranged from 503.93 to $2,179.42 \mathrm{mg} \mathrm{kg}^{-1}$ and 181.50 to $3,897.70 \mathrm{mg} \mathrm{kg}^{-1}$ with relative contributions of 32.0 to $59.3 \%$ and 21.3 to $57.3 \%$, respectively. Res-P ranged from 123.68 to $498.16 \mathrm{mg} \mathrm{kg}^{-1}$ with relative contribution of 7.3 to $18.4 \%$. The concentrations of KCl-P and $\mathrm{NaOH}-\mathrm{Po}$ were lower than the others, and ranged from 5.62 to $13.48 \mathrm{mg} \mathrm{kg}^{-1}$ and 8.57 to $215.58 \mathrm{mg} \mathrm{kg}^{-1}$ with relative contributions of 0.3 to $5.7 \%$ and 0.7 to $3.2 \%$, respectively. The concentrations of KCl-P, Ca-P, and Res-P decreased along the river flow direction (site 1 to site 5). The concentration of $\mathrm{NaOH}-\mathrm{Pi}$ decreased with the river flow except for site 3 . The concentration of NaOH-Pi was $567.55 \mathrm{mg} \mathrm{kg}^{-1}$ in site 3 , which was higher than that in sites 2,4 , and 5 . The concentrations of sites 2,4 , and 5 were 228.54, 181.50, and $194.54 \mathrm{mg} \mathrm{kg}^{-1}$, respectively.

Phosphorus-31 nuclear magnetic resonance assignments

${ }^{31}$ P-NMR spectra of NaOH-EDTA extracts of sediments The NMR spectra for the river sediments are shown in Fig. 3. Six ${ }^{31} \mathrm{P}$-NMR peaks from the $\mathrm{NaOH}-\mathrm{EDTA}$ extracts were observed. All NMR-spectra showed peaks in the area of phon$\mathrm{P}$ (12 to $23 \mathrm{ppm}$ ), ortho-P (6 to $7 \mathrm{ppm}$ ), mono-P (4 to $6 \mathrm{ppm}$ ), lipids-P (1 to $3 \mathrm{ppm})$, DNA-P (0 ppm), and pyro-P ( -3.5 to -4.5 ppm) (Turner et al. 2003a; Cade-Menun 2005; CadeMenun et al. 2006; Liu et al. 2009). Phon-P and lipids-P were not detected in sites 2 and 4 and sites 4 and 5, respectively.

The concentrations and relative distribution of various $\mathrm{P}$ compound groups in river sediments are presented in Table 2 . Po in the NaOH-EDTA fraction ranged from 85.59 to 1 , $671.42 \mathrm{mg} \mathrm{kg}^{-1}$, with the recovery rate ranging from 56.15 to $74.69 \%$. The ortho-P was the dominant form of $\mathrm{P}$ in the $\mathrm{NaOH}-\mathrm{EDTA}$ extracts of the river sediment, and ranged from 
Table 1 Properties of the sediments used in the experiments

\begin{tabular}{|c|c|c|c|c|c|c|c|c|c|c|c|c|}
\hline \multirow[t]{2}{*}{ Site } & \multirow[t]{2}{*}{$\mathrm{pH}$} & \multirow[t]{2}{*}{$\mathrm{OM}(\%)$} & \multicolumn{8}{|l|}{ Sediment } & \multicolumn{2}{|l|}{ Water } \\
\hline & & & $\begin{array}{l}\mathrm{TP} \\
\mathrm{mg} \mathrm{kg}^{-1}\end{array}$ & Po $(\%)$ & $\begin{array}{l}\mathrm{Al} \\
\mathrm{g} \mathrm{kg}^{-1}\end{array}$ & $\mathrm{Ca}$ & $\mathrm{Fe}$ & $\mathrm{Mg}$ & $\mathrm{Mn}$ & $\begin{array}{l}\mathrm{EC} \\
\mu \mathrm{s} \mathrm{cm}^{-1}\end{array}$ & $\begin{array}{l}\mathrm{TP} \\
\mathrm{mg} \mathrm{L}^{-1}\end{array}$ & $\begin{array}{l}\mathrm{EC} \\
\mu \mathrm{s} \mathrm{cm}^{-1}\end{array}$ \\
\hline 1 & 7.15 & 18.45 & $6,804.10$ & $2,909.98(42.8)^{\mathrm{a}}$ & 18.42 & 14.38 & 43.63 & 3.47 & 0.66 & $2,224.0$ & $2.23 \pm 0.71$ & $5,786.6$ \\
\hline 2 & 7.91 & 5.45 & $1,022.58$ & $204.84(20.0)$ & 18.17 & 17.19 & 35.74 & 4.10 & 0.57 & 422.2 & $3.48 \pm 0.43$ & $1,879.5$ \\
\hline 3 & 7.13 & 5.77 & $1,269.11$ & $245.32(19.3)$ & 31.71 & 12.87 & 36.44 & 4.00 & 0.43 & $1,636.0$ & $3.31 \pm 0.27$ & $3,177.9$ \\
\hline 4 & 8.02 & 4.15 & 852.38 & $168.88(19.8)$ & 29.71 & 13.23 & 37.55 & 3.73 & 0.50 & 459.9 & $2.97 \pm 0.20$ & $1,789.0$ \\
\hline 5 & 7.75 & 4.30 & 853.29 & 132.93 (15.6) & 20.07 & 14.72 & 34.38 & 4.06 & 0.53 & $1,518.0$ & $3.00 \pm 0.10$ & $2,855.7$ \\
\hline
\end{tabular}

${ }^{\mathrm{a}}$ The proportion of Po to TP in sediments (\%)

303.50 to $2,820.70 \mathrm{mg} \mathrm{kg}^{-1}$, accounting for 63.30 to $89.37 \%$ of TP in the NaOH-EDTA extracts. As another Pi component, the concentration of pyro-P was much less than for ortho-P, and ranged from 0.81 to $38.16 \mathrm{mg} \mathrm{kg}^{-1}$, accounting for 0.2 to $0.8 \%$ of TP in the sediment extracts. Mono-P was the dominant $\mathrm{Po}$ in the $\mathrm{NaOH}$-EDTA fraction of river sediments, and ranged from 33.71 to $1,318.04 \mathrm{mg} \mathrm{kg}^{-1}$, accounting for 9.0 to $29.6 \%$ of TP in the sediment extracts. DNA-P ranged from 5.09 to $90.37 \mathrm{mg} \mathrm{kg}^{-1}$, with relative contribution of 0.7 to $2.0 \%$ of the extracted $\mathrm{P}$ in river sediment. Lipids-P and phon$\mathrm{P}$ ranged from 2.55 to $118.70 \mathrm{mg} \mathrm{kg}^{-1}$ and 0.40 to $69.80 \mathrm{mg} \mathrm{kg}^{-1}$, with their relative contributions 0.2 to $2.7 \%$ and 0.1 to $1.6 \%$ of the extracted $\mathrm{P}$ in river sediments, respectively.

${ }^{31} \mathrm{P}-\mathrm{NMR}$ spectra of $\mathrm{NaOH}-\mathrm{TP}$ in $\mathrm{P}$ fractionation $\mathrm{The}{ }^{31} \mathrm{P}-$ NMR peaks of $\mathrm{NaOH}-\mathrm{TP}$ were different from the $\mathrm{NaOH}$ EDTA extracts. For the five sample sites, the peaks show six $\mathrm{P}$ compounds in the $\mathrm{NaOH}-\mathrm{TP}$ of $\mathrm{P}$ fraction in the sediments, including phon-P (12 to $23 \mathrm{ppm}$ ), ortho-P (6 to $7 \mathrm{ppm}$ ), mono$\mathrm{P}$ (4 to $6 \mathrm{ppm})$, lipids-P (1 to $3 \mathrm{ppm})$, DNA-P (0 ppm), and pyro-P ( -3.5 to -4.5 ppm) (Turner et al. 2003a; Cade-Menun 2005; Cade-Menun et al. 2006; Liu et al. 2009). Phon-P and
lipids-P were only detected in site 1. Pyro-P was not detected in sites 4 and 5 .

The concentrations and relative distribution of various $\mathrm{P}$ compound groups in $\mathrm{NaOH}-\mathrm{TP}$ extracts are presented in Table 2. Po in the NaOH-TP extract ranged from 8.57 to $215.58 \mathrm{mg} \mathrm{kg}^{-1}$, with the percent of TP in $\mathrm{NaOH}$ ranging from 1.56 to $11.48 \%$. The ortho-P was the dominant $\mathrm{P}$ in the NaOH-TP extracts, and ranged from 181.13 to $3,835.24 \mathrm{mg} \mathrm{kg}^{-1}$, accounting for 83.68 to $93.24 \%$ of TP in the NaOH-TP extracts. Mono-P was the dominant $\mathrm{Po}$ in the $\mathrm{NaOH}-\mathrm{TP}$ extracts of river sediments, and ranged from 15.24 to $220.29 \mathrm{mg} \mathrm{kg}^{-1}$, accounting for 5.36 to $13.16 \%$ of TP in the NaOH-TP extracts. DNA-P ranged from 3.56 to $23.57 \mathrm{mg} \mathrm{kg}^{-1}$, with a relative contribution of 0.57 to $2.53 \%$ of the $\mathrm{TP}$ in the $\mathrm{NaOH}-\mathrm{TP}$ extracts. As another $\mathrm{Pi}$, the concentration of pyro-P was much less than for ortho-P, ranging from 0 to $6.55 \mathrm{mg} \mathrm{kg}^{-1}$, accounting for 0 to $0.15 \%$ of $\mathrm{TP}$ in the NaOH-TP extracts. Lipids-P and phon-P ranged from 0 to $16.48 \mathrm{mg} \mathrm{kg}^{-1}$ and 0 to $11.15 \mathrm{mg} \mathrm{kg}^{-1}$, with their relative contribution being 0 to $0.40 \%$ and 0 to $0.27 \%$ of the extracted $\mathrm{P}$ in $\mathrm{NaOH}$ TP extracts, respectively.

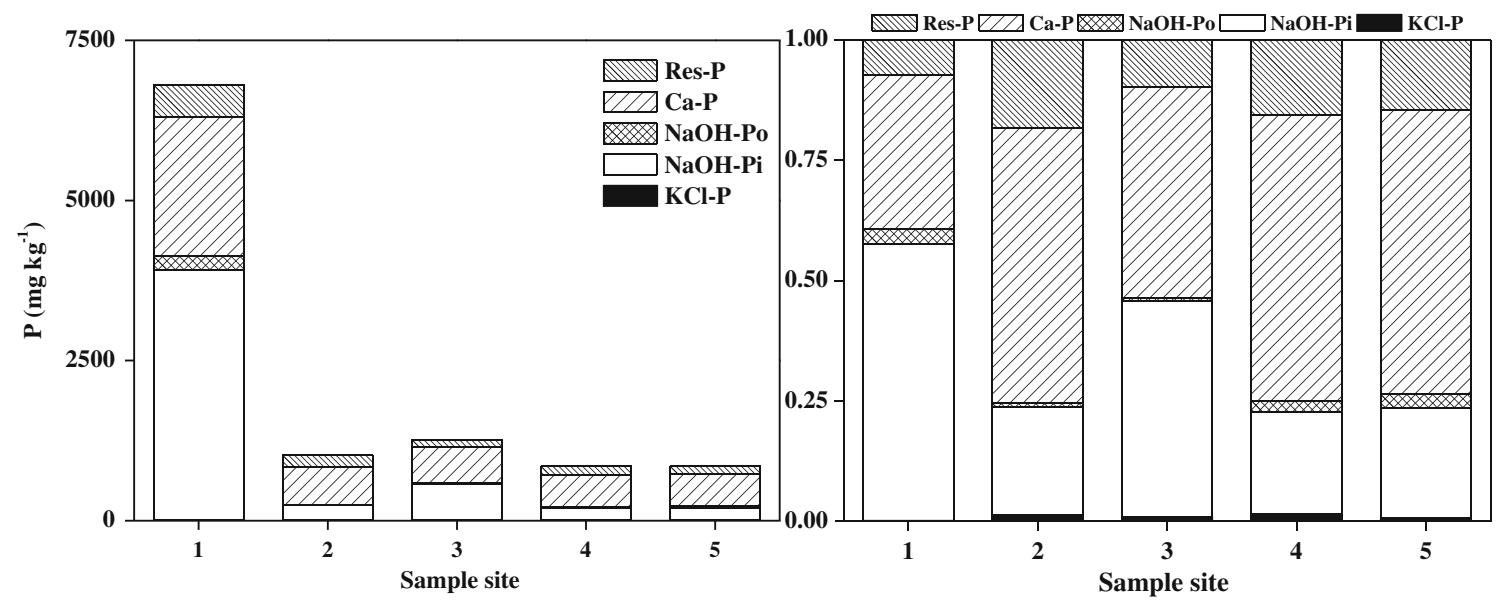

Fig. 2 Concentrations (left) and percentages (right) of $\mathrm{P}$ fractionations in the sediments 


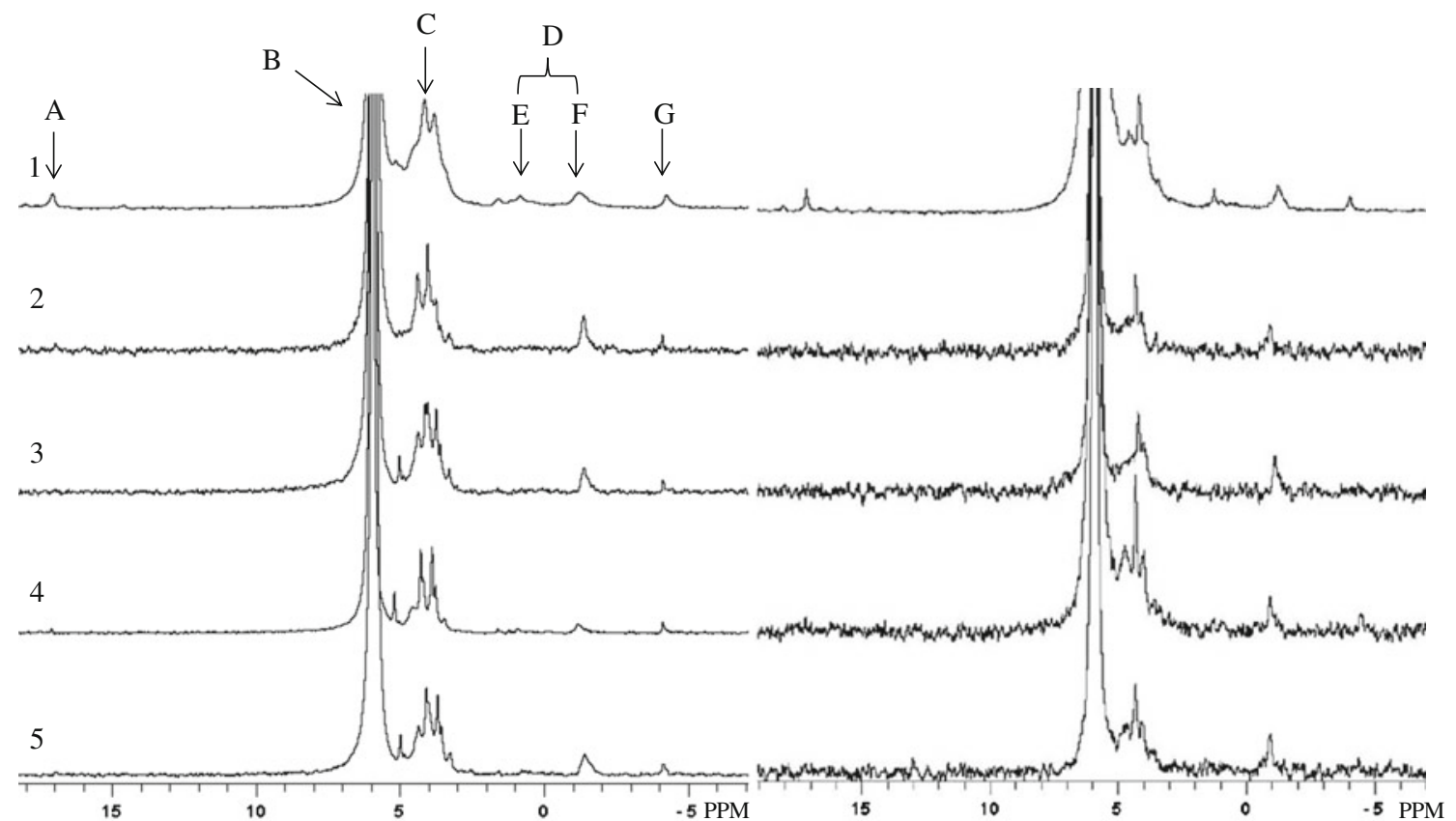

Fig. $3{ }^{31} \mathrm{P}-\mathrm{NMR}$ spectra of NaOH-EDTA extracts (left) and NaOH-TP extracts in $\mathrm{P}$ fraction (right) of the sediments in Fuyangxin river $(A$ phon-P, $B$ ortho-P, $C$ mono-P, $D$ diesters-P; $E$ lipids-P, $F$ DNA-P, $G$ pyro-P)

\section{Discussion}

Sediment $\mathrm{P}$ pollution in the artificial river

The P pollution in the Fuyangxin River system was serious. The average concentrations of TP and SRP in the water were 3.0 and $2.6 \mathrm{mg} \mathrm{L}^{-1}$, respectively, which means that the water pollution status surpasses grade $\mathrm{V}$ of the national quality standard, and that the water should not be used for any purpose. The concentration of TP and SRP were higher than Taihu Lake (TP, $0.12 \mathrm{mg} \mathrm{L}^{-1}$ ) and the Bronx River (TP, 0.438 and $0.089 \mathrm{mg} \mathrm{L}^{-1}$ ) (Bai et al. 2009; Wang and Pant 2011, 2012). The artificial river sediment $P$ had accumulated significantly, such that the concentration of TP in the sediment was

Table 2 Concentrations of $\mathrm{P}$ compounds in NaOH-EDTA extracts of the sediments determined by solution ${ }^{31} \mathrm{P}-\mathrm{NMR}$

\begin{tabular}{|c|c|c|c|c|c|c|c|c|}
\hline \multirow[t]{2}{*}{ Site } & \multirow{2}{*}{$\begin{array}{l}\mathrm{TP} \\
\mathrm{mg} \mathrm{kg}^{-1}\end{array}$} & \multirow[t]{2}{*}{ Po $(\%)$} & \multicolumn{2}{|l|}{$\mathrm{Pi}$} & \multicolumn{4}{|l|}{ Po } \\
\hline & & & Ortho-P & Pyro-P & Mono-P & Lipids-P & DNA-P & Phon-P \\
\hline 1 & $4,455.77$ & $1,671.42(57.4)^{\mathrm{a}}$ & $2,820.70(63.30)^{\mathrm{b}}$ & $38.16(0.86)$ & $1,318.04(29.58)$ & $118.70(2.66)$ & $90.37(2.03)$ & $69.80(1.57)$ \\
\hline 2 & 469.88 & $115.01(56.1)$ & $376.21(80.06)$ & $2.08(0.44)$ & $80.22(17.07)$ & $3.08(0.65)$ & $8.30(1.77)$ & n.d. \\
\hline 3 & 898.51 & $183.22(74.7)$ & $760.00(84.58)$ & $2.76(0.30)$ & $124.60(13.87)$ & $2.55(0.28)$ & $6.78(0.75)$ & $1.80(0.20)$ \\
\hline 4 & 367.57 & $105.65(62.6)$ & $303.50(82.56)$ & $1.01(0.27)$ & $58.04(15.79)$ & n.d. & $5.03(1.37)$ & n.d. \\
\hline 5 & 376.27 & $85.59(64.4)$ & $336.26(89.37)$ & $0.81(0.22)$ & $33.71(8.96)$ & n.d. & $5.09(1.35)$ & $0.40(0.11)$ \\
\hline \multicolumn{9}{|c|}{$\mathrm{NaOH}-\mathrm{TP}$ extracts in $\mathrm{P}$ fractionation analyzed by ${ }^{31} \mathrm{P}-\mathrm{NMR}$} \\
\hline 1 & $4,113.28$ & $215.58(5.24)^{\mathrm{c}}$ & $3,835.24(93.24)^{\mathrm{b}}$ & $6.55(0.16)$ & $220.29(5.36)$ & $16.48(0.40)$ & $23.57(0.57)$ & $11.15(0.27)$ \\
\hline 2 & 237.11 & $8.57(3.61)$ & $198.41(83.68)$ & $0.98(0.41)$ & $31.21(13.16)$ & n.d. & $6.50(2.74)$ & n.d. \\
\hline 3 & 576.53 & $8.98(1.56)$ & $524.13(90.91)$ & $1.24(0.22)$ & $46.92(8.14)$ & n.d. & $4.22(0.73)$ & n.d. \\
\hline 4 & 200.78 & $19.28(9.60)$ & $181.13(90.21)$ & n.d. & $15.24(7.59)$ & n.d. & $4.41(2.20)$ & n.d. \\
\hline 5 & 219.77 & $25.23(11.48)$ & $197.92(90.06)$ & n.d. & $18.29(8.32)$ & n.d. & $3.56(1.62)$ & n.d. \\
\hline
\end{tabular}

n.d. not detected

${ }^{\mathrm{a}}$ The proportion of Po in NaOH-EDTA extraction to total Po in sediments (\%)

${ }^{\mathrm{b}}$ The proportion of individual $\mathrm{P}$ fraction to total $\mathrm{P}$ in $\mathrm{NaOH}-\mathrm{EDTA}$ extraction

${ }^{\mathrm{c}}$ The proportion of $\mathrm{Po}$ to total $\mathrm{P}$ in $\mathrm{NaOH}-\mathrm{TP}$ of $\mathrm{P}$ fraction in river sediments 
$2,160.29 \mathrm{~m} \mathrm{~kg}^{-1}$. The concentration of $\mathrm{P}$ in the sediment was higher than that in soils, lake sediments, and marine sediment, and even compared with that found in manures (Table 3). Although the Fuyangxin River was constructed for flood control originally, the function of accepting sewage became more prominent with socio-economic development. Large cities and farmland are distributed on the banks of the river, so that the wastewater from the domestic and farm sources carries a large amount of $\mathrm{P}$ into the river, with the result that the concentration of $\mathrm{P}$ in the river sediment is high.

Pernet-Coudrier et al. (2012) reported that $4.4 \mathrm{tP} \mathrm{day}^{-1}$ was discharged into the Haihe river system with the wastewater from Beijing and its suburbs (Pernet-Coudrier et al. 2012). We could deduce that the wastewater from the cities of Shjiazhuang, Xingtai, and Hengshui introduced a large amount of P into the Fuyangxin River. Qu and Kroeze's (2010) study showed that the main sources of DIN and DIP were agriculture and sewage, respectively, between 1970 and 2000. They also predicted that these sources will be dominant in 2030 and 2050 (Qu and Kroeze 2010). Our study showed that the source of $\mathrm{P}$ was complicated and the emissions have continued increasing, which means that the source of $P$ was not only agriculture but also sewage (unpublished data). And the $\mathrm{P}$ pollution will be more serious in the future if it is not controlled.

${ }^{31} \mathrm{P}-\mathrm{NMR}$ spectroscopy and $\mathrm{P}$ fractionation

Our study showed that the $0.25 \mathrm{M} \mathrm{NaOH}+50 \mathrm{mM}$ EDTA fraction was an ideal extract for the study of Haihe River Basin sediments (unpublished data). Therefore, we chose to study the $0.25 \mathrm{M} \mathrm{NaOH}+50 \mathrm{mM}$ EDTA extract for Fuyangxin river sediments. The $\mathrm{NaOH}$ assured the high recovery of Po and EDTA can prevent the poly-P hydrolysis during extraction and reduce the concentration of paramagnetic ions, such as Fe and Mn (Hupfer et al. 1995; CadeMenun et al. 2002; Turner et al. 2005). The recovery of Po in $\mathrm{NaOH}-\mathrm{EDTA}$ to total Po in sediments was 56.15 to $74.69 \%$, which was an ideal recovery level for Po analysis (Zhang et al. 2009; Shinohara et al. 2012). The quality of ${ }^{31} \mathrm{P}-\mathrm{NMR}$ spectra in $\mathrm{NaOH}-\mathrm{TP}$ extracts was poorer than for $\mathrm{NaOH}$-EDTA; the main reasons may be that there was no EDTA in the $\mathrm{NaOH}-\mathrm{TP}$ extracts and much higher levels of paramagnetic ions (such as $\mathrm{Fe}$ and $\mathrm{Mn}$ ) existed in the extracts. Turner et al. (2006) reported that the Po in wetland soils was overestimated by alkaline extraction and molybdate colorimetry (Turner et al. 2006). The concentration of total Po derived from ${ }^{31} \mathrm{P}-\mathrm{NMR}$ analysis of NaOH-TP extracts was higher than that by $\mathrm{P}$ fractionation (excluding site 5). The main reason for this result was that some stable Po was not extracted by $0.1 \mathrm{M} \mathrm{NaOH}$, which was considered the stable Po (such as some inositol phosphates) belonging to Res-P in the $\mathrm{P}$ fraction system. The concentration of Po varied under different $\mathrm{pH}$, and some researcher suggested the better way to get more accurate results of sediment/soil samples is to remove $\mathrm{NaOH}$ before analysis with ${ }^{31} \mathrm{P}-\mathrm{NMR}$. But in this research (Wang and Pant 2010c), the result showed that use of the $0.25 \mathrm{M} \mathrm{NaOH}+$ $50 \mathrm{mM}$ EDTA extracts and solution ${ }^{31} \mathrm{P}-\mathrm{NMR}$ analysis was a more accurate method for quantifying Po in the river sediments than $\mathrm{P}$ fractionation.

\section{Biogenic P species}

In the Fuyangxin River sediment, biogenic $\mathrm{P}$ included phon-P, mono-P, lipid-P, DNA-P, and pyro-P. The concentration of biogenic-P ranged from 40.00 to $1,635.07 \mathrm{mg} \mathrm{kg}^{-1}$, accounting for 10.63 to $36.70 \%$. Poly-P was not detected in the $\mathrm{NaOH}-\mathrm{EDTA}$ extracts. Poly-P was considered to be a more labile form of $\mathrm{P}$ in the sediment that mineralizes more quickly (Hupfer et al. 2004; Reitzel et al. 2006a, b). This might be the reason there were no poly-P peaks observed in this research. Mono-P was the dominant biogenic-P in the NaOH-EDTA extracts of the river sediments. The inositol phosphates, from manures, plants, zooplankton, and algae, were the main compounds of mono-P, which were considered to be biounavailable, immobile, and refractory previously (Turner et al. 2002; Mckelvie 2007). Some studies, however, showed that the inositol phosphates were a possible source of phosphate release under anaerobic and aerobic conditions (Livingstone et al. 1982; Golterman et al. 1998). The concentration of DO in the surface water was $0.87 \mathrm{mg} \mathrm{L}^{-1}$, and the DO concentration at the sediment-water interface might be hypoxic. The main reason for the hypoxia-DO depletion was the high concentration of $\mathrm{NH}_{4}{ }^{+}-\mathrm{N}$ and $\mathrm{COD}_{\mathrm{Cr}}$ in the surface water. The concentration of $\mathrm{NH}_{4}{ }^{+}-\mathrm{N}$ and $\mathrm{COD}_{\mathrm{Cr}}$ were from 1.44 to $14.38 \mathrm{mg} \mathrm{L}^{-1}$ and 76.5 to $145.5 \mathrm{mg} \mathrm{L}^{-1}$ (based on the investigation from 2010 to 2012). Lots of the oxygenconsumption substances will deplete the $\mathrm{DO}$ in the river water. The mono-P would be mineralized under hypoxic conditions. Diesters-P was labile P in the sediment and its half-life was 21 years, and was a mixture compounds, such as DNA-P, lipids-P, and teichoic-P (Turner et al. 2003a; Ahlgren et al. 2005; Cade-Menun 2005). Pyro-P partially originated from esters or poly-P that was hydrolyzed during alkaline extraction (Hupfer et al. 1995). The diesters-P and pyro-P might the main $\mathrm{P}$ source in the river sediments.

$\mathrm{P}$ variation and the river systems

The P compounds showed different characteristics of change with the river flow. There were many dams in the river system in the Haihe River Basin for irrigation dating from 1960s, which were similar to the Bronx River (Kensico Dam) (Wang and Pant 2011, 2012). With the water scarcity, the operation of river dams caused intermittent fluctuations in flows (PernetCoudrier et al. 2012). Intermittent flows in a river system lead 
Table 3 Literature data concerning extracted TP from environmental samples

\begin{tabular}{lll}
\hline Samples & $\mathrm{TP}\left(\mathrm{mg} \mathrm{kg}^{-1}\right)$ & Literature \\
\hline River sediment (Bronx River, USA) & $138-2,730$ & Wang and Pant (2010a) \\
Soil (Everglades, USA) & $190-1,570$ & Dierberg et al. (2011) \\
Lake sediments (Taihu, China) & $399-1,830$ & Bai et al. (2009) \\
Manure (cattle, Deer and Sheep) & $5,584-7,919$ & McDowell et al. (2006) \\
Artificial lake sediments (China) & $888-1,984$ & Liu et al. (2009) \\
Marine sediment (Baltic Sea) & 1,371 & Ahlgren et al. (2006) \\
River sediment (North Canal River) & $654.9-1,285.4$ & Li et al. (2010) \\
River sediment (Haihe River Mainstream) & $928-2,528$ & An and Huang(2007) \\
\hline
\end{tabular}

to zero flow in some river segments, and also cause sediment accumulation at the front or behind dams. In this research, site 1 was located behind the Aixinzhuang Dam, which is a large dam for regulating the water for the Fuyang River and Fuyangxin River. The accumulation of sediment led to the TP and biogenic-P in site 1 being higher than other sites, at 6 , 804.10 and $1,635.07 \mathrm{mg} \mathrm{kg}^{-1}$, respectively. TP and biogenic$\mathrm{P}$ in the sediment was attenuated along the direction of flows because of the character of the artificial river, with their average relative proportion being 7.97:1.20:1.49:1.00:1.00 and 40.87:2.34:3.46:1.60:1 from upstream to downstream, respectively. The concentrations of TP and biogenic-P decreased 87 and $98 \%$ from site 1 to site 5 . The concentrations of TP and biogenic-P decreased to 853.29 and $40.00 \mathrm{mg} \mathrm{kg}^{-1}$ (Fig. 4). The P compounds showed different characteristics of change. The concentration of ortho-P, pyro-P, mono-P, and DNA-P were reduced along the river flow direction. Lipid-P was not detected at sites 4 and 5. Phon-P was found at sites 1 , 3 , and 5 . The main reason for the $P$ variation might be changes of the physical-chemical characteristics of the water and sediment along the flow direction (Wang and Pant 2010a). Site 1 was locates behind of the Aixinzhuang Dam, which was a large dam for regulation the water for Fuyang River and Fuyangxin River. The accumulation of sediment lead to the

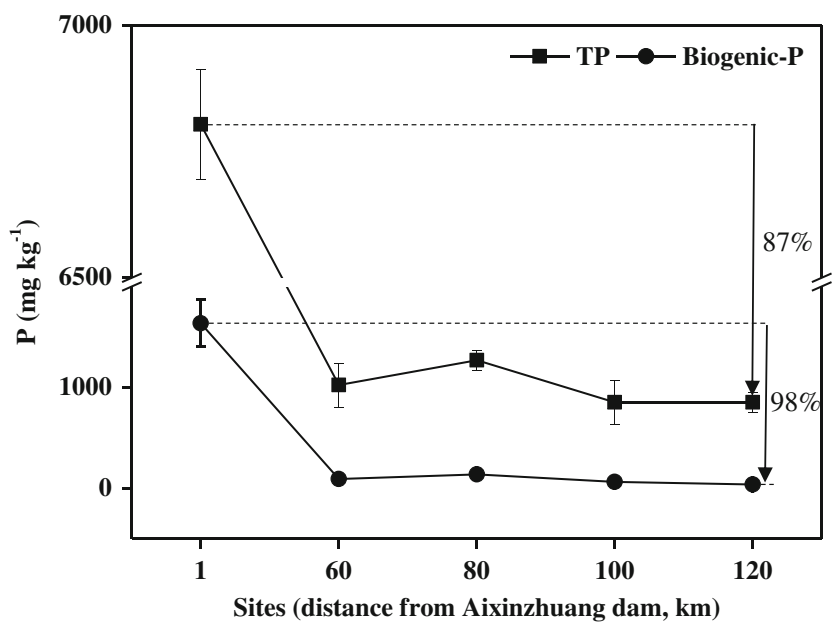

Fig. 4 The concentrations of TP and biogenic-P as the distance from Aixinzhuang dam (km)
TP and biogenic-P in site 1 was higher than other sites. From the upstream to the downstream, the sediment accepted the $\mathrm{P}$ from the surface water was decrease, and also part of biogenic$\mathrm{P}$ was mineralized. This phenomenon was not detected in the North Canal River (Li et al. 2010) and Bronx River (Wang and Pant 2010c).

\section{Conclusions}

This research revealed the $\mathrm{P}$ pollution status in terms of aspects of $\mathrm{P}$ species, distribution, and bioconversion in sediments of an artificial river affected by water scarcity and heavy pollution, the Fuyangxin River, by $\mathrm{P}$ fractionation and ${ }^{31} \mathrm{P}-\mathrm{NMR}$. We also evaluated the $\mathrm{P}$ fraction and ${ }^{31} \mathrm{P}-\mathrm{NMR}$ for biogenic-P analysis. The average concentrations of TP and SRP in the water were 3.0 and $2.6 \mathrm{mg} \mathrm{L}{ }^{-1}$, respectively, which means that the water pollution status surpasses grade $\mathrm{V}$ of the national quality standard and the water should not be used for any purpose. The river sediments accumulated significant Pi and Po. The rank order of the $\mathrm{P}$ fractions was as follows: $\mathrm{Ca}-\mathrm{P}>\mathrm{NaOH}-\mathrm{Pi}>\mathrm{Res}-\mathrm{P}>\mathrm{KCl}-\mathrm{P}>\mathrm{NaOH}-\mathrm{Po}$, with their average relative proportion 25.1:16.8:6.6:1.7:1:0. Six P compounds were detected in $\mathrm{NaOH}-\mathrm{EDTA}$ extracts by ${ }^{31} \mathrm{P}$ NMR. Mono-P (8.96-29.58 \%) was the dominant forms of biogenic-P, and other smaller components of biogenic-P were also observed, including pyro-P (0.22-0.86 \%), DNA-P (0.75-2.03\%), phon-P (0-1.57\%), and lipids-P (0-2.66\%). Along the direction of flows, the TP and biogenic-P decreased, with their average relative proportion 7.97:1.20:1.49:1.00:1.00 and 40.87:2.34:3.46:1.60:1 from upstream to downstream, respectively. The concentration and species of $\mathrm{Po}$ in the $\mathrm{NaOH}-\mathrm{Po}$ fraction were lower than was found by ${ }^{31} \mathrm{P}-\mathrm{NMR}$ analysis in this research. Thus the use of $0.25 \mathrm{M} \mathrm{NaOH}+50 \mathrm{mM}$ EDTA extracts and solution ${ }^{31} \mathrm{P}$ NMR analysis was a more accurate method for quantifying biogenic- $\mathrm{P}$ in the river sediments than $\mathrm{P}$ fractionation.

Acknowledgments We thank Dr. Jingxin Yang and Dr. Hongwei $\mathrm{Li}$ for ${ }^{31} \mathrm{P}-\mathrm{NMR}$ analysis (Beijing Nuclear Magnetic Resonance 
Center). This work was supported by the National Natural Science Foundation of China (grant no. 20907067 and 21107126) and the National Water Pollution Control and Management Technology Major Projects of China (2012ZX07203-006).

\section{References}

Ahlgren J, Tranvik L, Gogoll A, Waldebäck M, Markides K, Rydin E (2005) Sediment depth attenuation of biogenic phosphorus compounds measured by ${ }^{31}$ P NMR. Environ Sci Technol 39(3):867-872

Ahlgren J, Reitzel K, Tranvik L, Gogoll A, Rydin E (2006) Degradation of organic phosphorus compounds in anoxic Baltic Sea sediments: $\mathrm{a}^{31} \mathrm{P}$ nuclear magnetic resonance study. Limnol Oceanogr 51(5):23412348

An M, Huang SL (2007) Distribution and correlation between total content of phosphorus, iron and organic matter of surface sediment in Haihe River mainstream. Res Environ Sci 20(3):63-67 (in Chinese)

Aspila KI, Agemian H, Chau ASY (1976) A semi-automated method for the determination of inorganic organic and total phosphate in sediments. Analyst 101:187-197

Bai XL, Ding SM, Fan CX, Liu T, Shi D, Zhang L (2009) Organic phosphorus species in surface sediments of a large shallow, eutrophic lake, Lake Taihu, China. Environ Pollut 157(8-9):2507-2513

Brandes JA, Ingall ED, Paterson D (2007) Characterization of minerals and organic phosphorus species in marine sediments using soft Xray fluorescence spectromicroscopy. Mar Chem 103(3-4):250-265

Cade-Menun BJ (2005) Characterizing phosphorus in environmental and agricultural samples by ${ }^{31} \mathrm{P}$ nuclear magnetic resonance spectroscopy. Talanta 66(2):359-371

Cade-Menun BJ, Liu CW, Nunlist R, McColl JG (2002) Soil and litter phosphorus-31 nuclear magnetic resonance spectroscopy: extractants, metals, and phosphorus relaxation times. J Environ Qual 31(2):457-465

Cade-Menun BJ, Benitez-Nelson CR, Pellechia P, Paytan A (2005) Refining ${ }^{31} \mathrm{P}$ nuclear magnetic resonance spectroscopy for marine particulate samples: storage conditions and extraction recovery. Mar Chem 97(3-4):293-306

Cade-Menun BJ, Navaratnam JA, Walbridge MR (2006) Characterizing dissolved and particulate phosphorus in water with ${ }^{31} \mathrm{P}$ nuclear magnetic resonance spectroscopy. Environ Sci Technol 40(24): 7874-7880

Cardoza LA, Korir AK, Otto WH, Wurrey CJ, Larive CK (2004) Applications of NMR spectroscopy in environmental science. Prog Nucl Magn Reson Spectrosc 45:209-238

Carpenter SR (2008) Phosphorus control is critical to mitigating eutrophication. Proc Natl Acad Sci U S A 105(12):11039-11040

Dierberg FE, Debusk TA, Larson NR, Kharbanda MD, Chan N, Gabriel MC (2011) Effects of sulfate amendments on mineralization and phosphorus release from South Florida (USA) wetland soils under anaerobic conditions. Soil Biol Biochem 43(1):31-45

Golterman HL (2001) Phosphate release from anoxic sediments or 'What did Mortimer really write?'. Hydrobiologia 450(1-3):99-106

Golterman H, Paing J, Serrano L, Gomez E (1998) Presence of and phosphate release from polyphosphates or phytate phosphate in lake sediments. Hydrobiologia 364:99-104

Hieltjes AHM, Lijklema L (1980) Fractionation of inorganic phosphorus in calcareous sediments. J Environ Qual 9(3):405-407

Hupfer M, Gächter R, Ruegger H (1995) Polyphosphate in lake sediments: 31P NMR spectroscopy as a tool for its identification. Limnol Oceanogr 40(3):610-617

Hupfer M, Rübe B, Schmieder P (2004) Origin and diagenesis of polyphosphate in lake sediments: a ${ }^{31} \mathrm{P}-\mathrm{NMR}$ study. Limnol Oceanogr 49(1):1-10
Jensen HS, Kristensen P, Jeppesen E, Skytthe A (1992) Iron:phosphorus ratio in surface sediment as an indicator of phosphate release from aerobic sediments in shallow lakes. Hydrobiologia 235/236(1):731743

Li N, Shan BQ, Zhang H, Zhang JL (2010) Organic phosphorus forms in the sediments in the downstream channel of North Canal River watershed. Environ Sci 31(12):2911-2916 (in Chinese)

Liu JY, Wang H, Yang HJ, Ma YJ, Cai OC (2009) Detection of phosphorus species in sediments of artificial landscape lakes in China by fractionation and phosphorus-31 nuclear magnetic resonance spectroscopy. Environ Pollut 157(1):49-56

Livingstone D, Khoja TM, Whitton BA (1982) Laboratory studies on phosphorus sources for an upper teesdale uk calothrix parietina. $\mathrm{Br}$ Phycol J 17:235

McDowell RW, Stewart I, Cade-Menun BJ (2006) An examination of spin-lattice relaxation times for analysis of soil and manure extracts by liquid state phosphorus-31 nuclear magnetic resonance spectroscopy. J Environ Qual 35(1):293-302

Mckelvie ID (2007) Inositol phosphates in aquatic systems. In: Turner BL, Richardson AE, Mullaney EJ (eds) Inositol phosphates link agriculture and the environment. CABI, UK, pp 261-277

Murphy J, Riley JP (1962) A modified single solution method for the determination of phosphate in nature waters. Anal Chim Acta 27:31-36

Orchard ED, Benitez-Nelson CR, Pellechia PJ, Lomas MW, Dyhrman ST (2010) Polyphosphate in Trichodesmium from the low-phosphorus Sargasso Sea. Limnol Oceanogr 55(5):2161-2169

Pernet-Coudrier B, Qi WX, Liu HJ, Müller B, Berg M (2012) Sources and pathways of nutrients in the semi-arid region of Beijing-Tianjin, China. Environ Sci Technol 46(10):5294-5301

Pierzynski GM (2004) Methods of phosphorus analysis for soils, sediments, residuals, and waters. Southern Cooperative Series Bulletin No.396. North Carolina State University Press, Raleigh

Qu HJ, Kroeze C (2010) Past and future trends in nutrients export by rivers to the coastal waters of China. Sci Total Environ 408(9):2075-2086

Reitzel K, Ahlgren J, Gogoll A, Jensen HS, Rydin E (2006a) Characterization of phosphorus in sequential extracts from lake sediments using ${ }^{31} \mathrm{P}$ nuclear magnetic resonance spectroscopy. Can J Fish Aquat Sci 63(8):1686-1699

Reitzel K, Ahlgren J, Gogoll A, Rydin E (2006b) Effects of aluminum treatment on phosphorus, carbon, and nitrogen distribution in lake sediment: a ${ }^{31}$ P NMR study. Water Res 40(4):647-654

Reitzel K, Ahlgren J, Debrabandere H, Waldebäck M, Gogoll A, Tranvik L, Rydin E (2007) Degradation rates of organic phosphorus in lake sediment. Biogeochemistry 82(1):15-28

Reitzel K, Jensen HS, Flindt M, Andersen F (2009) Identification of dissolved nonreactive phosphorus in freshwater by precipitation with aluminum and subsequent ${ }^{31} \mathrm{P}$ NMR analysis. Environ Sci Technol 43(14):5391-5397

Rusu V, Postolachi L, Povar I, Alder A, Lupascu T (2012) Dynamics of phosphorus forms in the bottom sediments and their interstitial water for the Prut River (Moldova). Environ Sci Pollut Res 19(8):3126-3131

Schauser I, Chorus I, Lewandowski J (2006) Effects of nitrate on phosphorus release: comparison of two Berlin lakes. Acta Hydrochim Hydrobiol 34(4):325-332

Shinohara R, Imai A, Kawasaki N, Komatsu K, Kohzu A, Miura S, Sano T, Satou T, Tomioka N (2012) Biogenic phosphorus compounds in sediment and suspended particles in a shallow eutrophic lake: $\mathrm{a}^{31} \mathrm{P}$ nuclear magnetic resonance $\left({ }^{31} \mathrm{P}\right.$ NMR) study. Environ Sci Technol 46(19):10572-10578

Turner BL, Papházy MJ, Haygarth PM, Mckelvie ID (2002) Inositol phosphates in the environment. Phil Trans R Soc B 357(1420): 449-469

Turner BL, Mahieu N, Condron LM (2003a) Phosphorus-31 nuclear magnetic resonance spectral assignments of phosphorus compounds in soil NaOH-EDTA extracts. Soil Sci Soc Am J 67(2):497-510 
Turner BL, Mahieu N, Condron LM (2003b) The phosphorus composition of temperate pasture soils determined by $\mathrm{NaOH}$-EDTA extraction and solution ${ }^{31}$ P NMR spectroscopy. Org Geochem 34(8):1199-1210

Turner BL, Cade-Menun BJ, Condron LM, Newman S (2005) Extraction of soil organic phosphorus. Talanta 66(2):294-306

Turner BL, Newman S, Reddy KR (2006) Overestimation of organic phosphorus in wetlands soils by alkaline extraction and molybdate colorimetry. Environ Sci Technol 40(10):3349-3354

Wang JY, Pant HK (2010a) Enzymatic hydrolysis of organic phosphorus in river bed sediments. Ecol Eng 36(7):963-968

Wang JY, Pant HK (2010b) Phosphorus sorption characteristics of the Bronx River bed sediments. Chem Speciat Bioavailab 22(3):171-181
Wang JY, Pant HK (2010c) Identification of organic phosphorus compounds in the Bronx River bed sediments by phosphorus-31 nuclear magnetic resonance spectroscopy. Environ Monit Assess 171(1-4): 309-319

Wang JX, Pant H (2011) Land use impact on bioavailable phosphorus in the Bronx river, New York. J Environ Prot 2:342-358

Wang JX, Pant H (2012) Estimation of phosphorus bioavailability in the water column of the Bronx river, New York. J Environ Prot 3:316323

Zhang RY, Wu FC, He ZQ, Zheng J, Song BA, Jin LH (2009) Phosphorus composition in sediments from seven different trophic lakes, China: a phosphorus-31 NMR study. J Environ Qual 38(1):353-359 